\title{
A new species and new records of avian nasal mites (Acarina: Rhinonyssidae) from Japan
}

\author{
Teruki Kadosaka, ${ }^{*}$ Kiyotoshi Kaneko* and Kiyoshi Asanuma ${ }^{* *}$ \\ *Department of Parasitology, Aichi Medical University, Nagakute-cho, \\ Aichi-gun 480-11, Japan \\ ** Department of Zoology, National Science Museum, Hyakunin-cho, \\ Shinjuku-ku, Tokyo 160, Japan
}

(Received: May 17, 1986)

Key words: nasal mite, Rhinonyssidae, taxonomy, Japan.

\begin{abstract}
A new and seven newly recorded species of the avian nasal mites (Rhinonyssidae) are reported from birds in Japan. A new species, Ptilonyssus hiyodori n. sp. is described on the female. Seven species, Ptilonyssus ruandae Fain, 1956, Ptilonyssus sairae Castro, 1948, Ptilonyssus euroturdi Fain and Hyland, 1963, Rhinonyssus himantopus Strandtmann, 1951, Sternostoma technaui (Vitzthum). 1935, Rallinyssus caudistigmus Strandtmann, 1948, and Ruandanyssus terpsiphonei Fain, 1957, new to Japan are briefly redescribed on available specimens and figured. All the Japanese rhinonyssid mites are listed on a table.
\end{abstract}

Japanese species of the family Rhinonyssidae have been studied by several authors (Kaneko, 1973, 1977; Kaneko et al., 1978; Ehara, 1980; Kadosaka et al., 1983). The Rhinonyssidae are so far composed of the 11 genera, and three of them, namely, Ptilonyssus Berlese and Trouessart, 1889, Rhinonyssus Trouessart, 1894 and Tinaminyssus Strandtmann and Wharton, 1958, are known from Japan, and four Ptilonyssus, one Rhinonyssus and two Tinaminyssus species have already been recorded. They are Ptilonyssus dioptrornis, $P$. enicuri, $P$. emberizae, $P$. pari, Rhinonyssus rhinolethrum, Tinaminyssus columbae and $T$. mellori. A new species and 7 other species new to Japan are dealt with in this paper. All the material is based on the collection made by one

* 角坂照貴, 金子清俊: 愛知医科大学寄生虫学教室 (宁480-11 愛知県愛知郡長久手町)

** 浅沼 端: 国立科学博物館動物研究部 (下160 東 京都新宿区百人町）
(K.A.) of us and is deposited in the collections of the National Science Museum, Tokyo. Birds were identified using "A HandList of the Japanese Birds" (Hachisuka et al., 1958).

\section{Ptilonyssus ruandae Fain, 1956}

(Fig. 1)

Ptilonyssus ruandae Fain, 1956, Rev. Zool. Bot. Afr., 53: 395.

Ptilonyssus ruandae alcippei Fain and Nadchatram, 1962, Bull. Ann. Soc. R. Entomol. Belg., 98: 279.

Female. Idiosoma $670 \mu \mathrm{m}$ long and 340 $\mu \mathrm{m}$ wide; elongate oval in shape; lateral margin slightly concaved at level of coxae IV.

Dorsum: Podosomal plate $195 \mu \mathrm{m}$ long and $250 \mu \mathrm{m}$ wide; anterior margin slightly concaved and posterior margin rounded; 3 pairs of minute setae and 2 pairs of strong ones of approximately $45 \mu \mathrm{m}$ long present between plate and stigmata. Pygidial plate 
Table 1 List of rhinonyssid nasal mites from Japanese birds.

\begin{tabular}{|c|c|c|c|}
\hline Mite species & Host species & Host family & Reference \\
\hline Ptilonyssus ruandae & Zosterops palpebrosa japonica & Zosteropidae & New record \\
\hline$P$. sairae & Chloris sinia minor & Fringillidae & New record \\
\hline P. euroturdi & Turdus naumanni euromus & Turdidae & New record \\
\hline P. hiyodori & Hypsipetes amaurotis amaurotis & Pycnonotidae & New species \\
\hline P. dioptrornis & $\begin{array}{l}\text { Muscicapa cyanomelana } \\
\text { cyanomelana }\end{array}$ & Muscicapidae & $\begin{array}{l}\text { Kadosaka } e t \\
\text { al. }(1983)\end{array}$ \\
\hline P. enicuri & Erithacus akahige akahige & Turdidae & $\begin{array}{l}\text { Kadosaka } \text { et } \\
\text { al. }(1983)\end{array}$ \\
\hline P. emberizae & Emberiza spodocephala personata & Emberizae & $\begin{array}{l}\text { Kadosaka } e t \\
\text { al. (1983) }\end{array}$ \\
\hline P. pari & $\begin{array}{l}\text { Parus major minor } \\
P . \text { ater insularis } \\
P . \text { varius varius }\end{array}$ & Paridae & $\begin{array}{l}\text { Kadosaka } e t \\
\text { al. }(1983)\end{array}$ \\
\hline Rhinonyssus rhinolethrum & $\begin{array}{l}\text { Anas penelope } \\
\text { A. crecca crecca } \\
\text { A. acuta acuta } \\
\text { A. clypeata } \\
\text { A. poecilorhyncha zonorhyncha } \\
\text { A. platyrhynchos platyrhynchos }\end{array}$ & Anatidae & $\begin{array}{l}\text { Kaneko et } \\
\quad \text { al (1978) }\end{array}$ \\
\hline R. himantopus & Charadrius placidus japonicus & Charadriidae & New record \\
\hline Sternostoma technaui & $\begin{array}{l}\text { Turdus naumanni euromus } \\
T . \text { dauma toratugumi }\end{array}$ & Turdidae & New record \\
\hline Rallinyssus caudistigmus & Gallinula chloropus indica & Rallidae & New record \\
\hline Ruandanyssus terpsiphone & Pericrotus roseus divaricatus & Campephagidae & New record \\
\hline Tinaminyssus columbae & Streptopelia orientalis orientalis & Columbidae & Kaneko (1973) \\
\hline T. melloi & $S$. orientalis orientalis & Columbidae & Kaneko (1973) \\
\hline
\end{tabular}

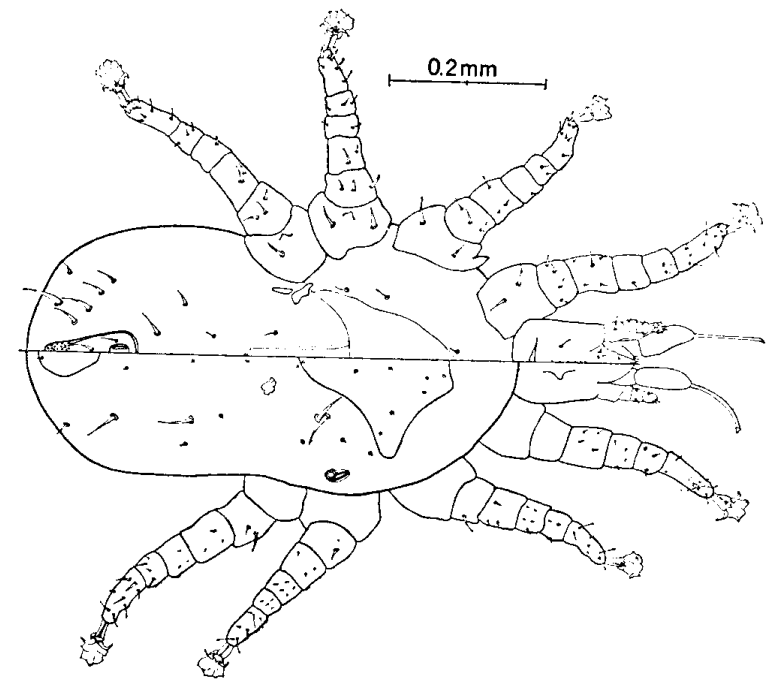

Fig. 1 Ptilonyssus ruandae: dorsal (right) and ventral (left) halves.
$80 \mu \mathrm{m}$ long and $66 \mu \mathrm{m}$ wide, roughly oval in shape, with a pair of minute setae terminally. Venter: Nine pairs of simple setae (15-42 $\mu \mathrm{m}$ in length) on opisthosoma. Legs: Coxal setal formula 2.2.2.1, all simple setae; coxa II with strong sharply pointed process on antero-dorsal margin, tarsi II-IV each with 3 pairs of stout setae (approximately $17 \mu \mathrm{m}$ in length) ventrodistally.

New records in Japan: 3우, from Zosterops palpebrosa japonica, Japanese WhiteEye (Zosteropidae), Miyake Island, Tokyo Pref., Feb. 1952 and 17 Apr., 1954.

Previous records: Ptilonyssus ruandae was originally described as a parasite in Zosterops senegalensis (Zosteropidae) in Ruanda-Urundi (Fain, 1956b) and was illustrated later (Fain, 1957a). Domrow (1964) recorded the mite from Zosterops lateralis in Australia. 
Subspecies $P . r$. alcippei Fain and Nadchatram, 1962, collected from Alicippe nipalensis peracensis (Timaliidae) in Malaysia. Fain (1963a) described another subspecies $P$. $r$. sylviae Fain, 1963, from Sylvia atricapilla atricapilla and $S$. communis communis in Belgium. Butenko (1969) also reported $P$. ruandae from birds in USSR.

\section{Ptilonyssus sairae Castro, 1948}

(Fig. 2)

Ptilonyssus sairae Castro, 1948, Arq. Inst. Biol. Sao Paulo, 18: 260.

Ptilonyssus japuibensis Castro, 1948, Arq. Inst. Biol. Sao Paulo, 18: 263.

Ptilonyssus constrictus Ford, 1961, Acarologia, 3: 140.

Ptilonyssus agelaii Fain and Aitken, 1967, Bull. Inst. R. Sci. Nat. Belg., 43: 7.

Ptilonyssus japuibensis cyanocompsae Fain and Aitken, 1969, Bull. Ann. Soc. R. Entomol. Belg., 105: 354.

Ptilonyssus teretistris Černý, 1969, Folia Parasitol. (Prague), 16: 227.

Ptilonyssus ludovicianus Černý, 1969, Folia Parasitol. (Prague), 16: 228.

Ptilonyssus constrictus longisetosus Černý and Dusbábek, 1970, Acarologia, 12: 481.

Ptilonyssus garridoi Cruz, 1971, Poeyana Inst. Biol. Acad. Cienc. Cuba., 90: 1.

Female. Idiosoma $780 \mu \mathrm{m}$ long by 350 $\mu \mathrm{m}$ wide, elongate oval in shape; lateral

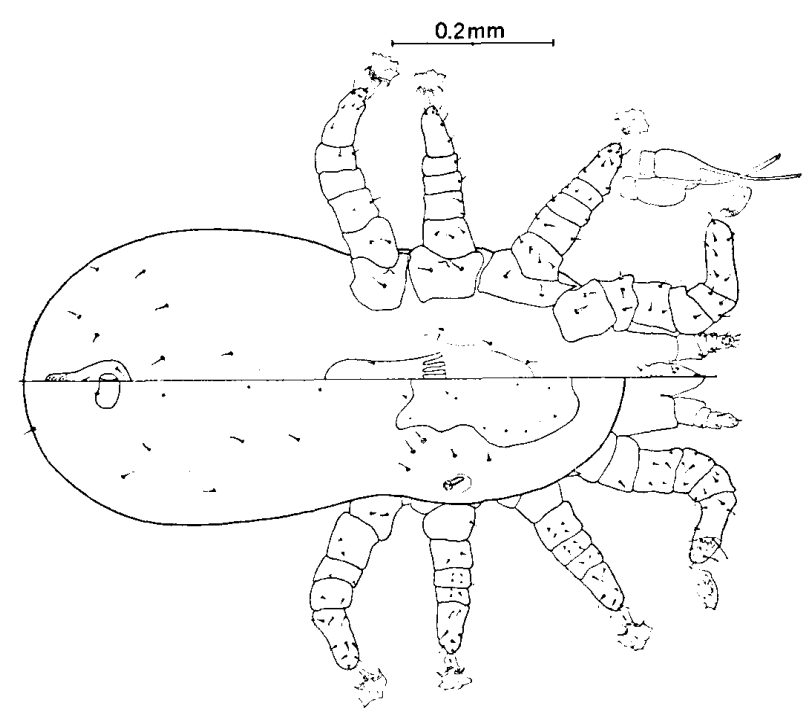

Fig. 2 Ptilonyssus sairae: dorsal (right) and ventral (left) halves. margin slightly concaved at level of coxae IV.

Dorsum: Podosomal plate $230 \mu \mathrm{m}$ long by $175 \mu \mathrm{m}$ wide, strongly sclerotized, strongly concaved laterally, slightly projected posterolaterally as in Fig. 2, and with 10 pairs of minute setae; anterior and posterior margins concaved. A pair of minute setae posteriorly off the plate. Five simple setae (approximately $20 \mu \mathrm{m}$ maximum in length) flanking podosomal plate. Opisthosoma with 3 pairs of minute and 6 pairs of simple setae (5-15 $\mu \mathrm{m}$ long). Pygidial plate $30 \mu \mathrm{m}$ in length and $75 \mu \mathrm{m}$ in width, heavily sclerotized, with a pair of simple setae; posterior margin concaved.

Venter: Sternal plate indistinctliy outlined and without striation. Three pairs of setae on soft integument. Genital plate weakly sclerotized, with a pair of genital setae on lateral margins. Seven pair of simple setae on opisthosoma. Anal plate roughly triangle in shape, $108 \mu \mathrm{m}$ long by $58 \mu \mathrm{m}$ wide; a pair of adanal setae at level of anterior margin of anus; post-anal seta at posterior region of the plate.

Leg: Coxal setal formula 2.2.2.1, all simple setae; coxa II with strong process on anterodorsal margin as in Fig. 2, tarsi II-IV each with 3 pairs of stout setae $(15 \mu \mathrm{m}$ in length) ventro-distally.

New records in Japan: 13 \% 9 , from Chloris sinica minor, Small Japanese Greenfinch (Fringillidae), Shizuoka Pref., 27 Feb., 1955 and 13 Apr., 1956.

Previous records: This species was originally described by Castro (1948) from Tangara seledon (Thraupidae) in Brazil. The mite parasitizes birds of the families Thraupidae, Fringillidae, Icteridae, Tyrannidae, Paridae and Parulidae in the New World (Ford, 1961; George, 1961; Fain and Aitken, 1967, 1968, 1969; Černý and Dusbábek, 1970; Hyland and Moorhouse, 1970; Cruz, 1971; Pence, 1972c, 1973; Pence and Castro, 1976; Spicer, 1977, 1978, 1984; Wilson and Haas, 1980). Pence (1973) and Pence and Castro (1976) reported that $P$. japuibensis, $P$. $j$. cyanocompsae, $P$. constrictus, $P$. c. longisetosus, $P$. agelaii, $P$. teretistris, $P$. ludovicianus and $P$. garridoi were considered as a synonym of $P$. sairae. 


\section{Ptilonyssus euroturdi Fain and Hyland, 1963}

(Fig. 3)

Ptilonyssus euroturdi Fain and Hyland, 1963, Bull. Ann. Soc. R. Entomol. Belg., 99: 381.

Ptilonyssus euroturdi mimicola Fain and Hyland, 1963, Bull. Ann. Soc. R. Entomol. Belg., 99: 384 .

Female. Idiosoma $1,100 \mu \mathrm{m}$ long by 630 $\mu \mathrm{m}$ wide, elongate oval in shape.

Dorsum: Podosomal plate $300 \mu \mathrm{m}$ long by $260 \mu \mathrm{m}$ wide; anterior margin straight or slightly concaved and posterior margin irregular and indistinct. Plate flanked by 5 stout setae (approximately $45 \mu \mathrm{m}$ maximum in length) postero-laterally and by a pair of minute setae posteriorly. Pygidial plate sclerotized, rather straight anteriorly and concaved posteriorly, $70 \mu \mathrm{m}$ long by $90 \mu \mathrm{m}$ wide, with a pair of spinous setae at posterior border and a pair of minute pores or tiny setae laterally. Venter: Sternal plate weakly sclerotized, and outlined irregularly and indistinctly; 1st and 2nd sternal setae on the plate, 3rd ones on soft integument. Opisthosoma with 8 pairs of spinous setae.

New records in Japan: 55우, from Turdus naumanni euromus, Dusky Thrush (Turdidae), Gifu Pref., 14 Nov., 1979 and 18 Dec., 1980.

Previous records: This mite was originally described as the parasite of the family Turdidae, Turdus viscivorus viscivorus and

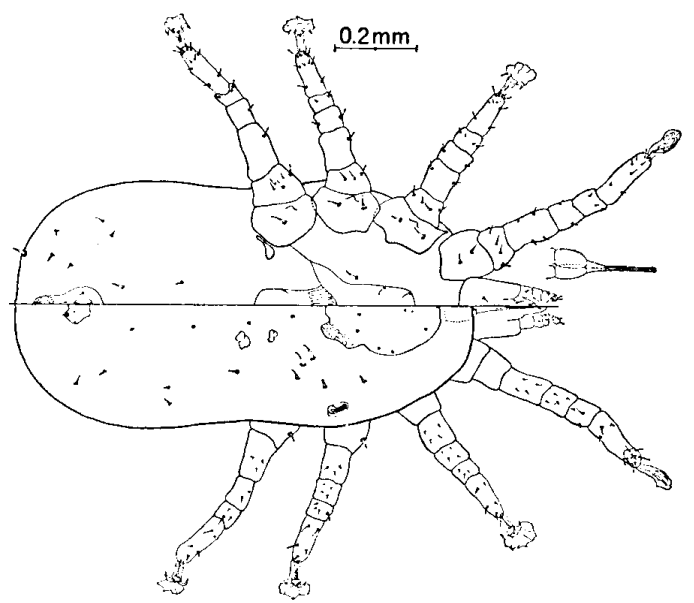

Fig. 3 Ptilonyssus euroturdi: dorsal (right) and ventral (left) halves.
$T$. ericetorum ericetorum ( $=T$. philomelus clarkei) in Belgium by Fain and Hyland (1963). The subspecies P. euroturdi mimicola collected from Dumetella carolinensis (Turdidae) in North America is synonymous with $P$. euroturdi. Accordingly, the mite has so far been recorded from Turdus fumigatus and $T$. nudigenis in Trinidad (Fain and Aitken, 1969), T. pilaris and T. viscivorus in Roumania (Feider and Mironescu, 1968), birds in USSR (Butenko, 1969), T. murula and T. philomelus in New Zealand (Ramsay, 1970; Domrow, 1972), Hylocichla mustelina and Dumetella carolinensis in North America (Pence, 1972c), Catharus dryas in Guatemala(Spicer, 1984) and Turdus murula in Austria (Fain et al., 1974). This mite is recorded only from the nasal passage of the family Turdidae.

\section{Ptilonyssus hiyodori n. sp.}

(Fig. 4)

Female. Idiosoma 750-1,050 $\mu \mathrm{m} \quad(900$ $\mu \mathrm{m})$ long by $420-550 \mu \mathrm{m}(450 \mu \mathrm{m})$ wide, elongate oval; lateral margin slightly concaved at level of coxae IV.

Dorsum: Podosomal plate well developed, $285 \mu \mathrm{m}$ long by $335 \mu \mathrm{m}$ wide; anterior margin straight and posterior margin rounded; 9 pairs of minute blunt-tipped setae on the plate, and flanked by 5 pairs of minute setae with blunt tips. Pygidial plate $85 \mu \mathrm{m}$ long

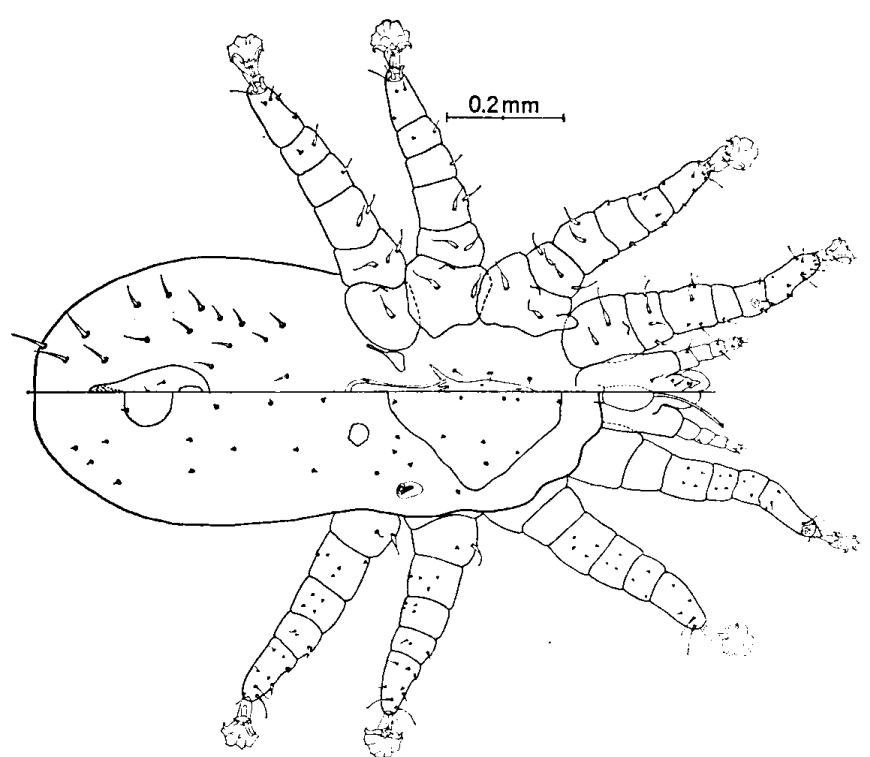

Fig. 4 Ptilonyssus hiyodori n. sp.: dorsal (right) and ventral (left) halves. 
by $100 \mu \mathrm{m}$ wide, strongly sclerotized, with paired pygidial setae terminally. Opisthosoma with 12 pairs of minute setae with blunt tips (approximately $7 \mu \mathrm{m}$ in length). Peritreme including stigma at level of coxae IV $32 \mu \mathrm{m}$ long.

Venter: Sternal plate very weakly sclerotized, outlined indistinctly and without striations; 3 pairs of sternal setae on soft integument (approximately $20 \mu \mathrm{m}$ long). Genital plate narrow, strongly sclerotized, $150 \mu \mathrm{m}$ long by $33 \mu \mathrm{m}$ wide. Opisthosoma with 16 pairs of simple long setae (22-62 $\mu \mathrm{m}$ long), with posterior setae longer than preceding ones. Anal plate pear-shaped, $195 \mu \mathrm{m}$ long by $80 \mu \mathrm{m}$ wide with well developed cribrum; anus close to anterior margin of the plate; adanal setae situated posterior to anus.

Legs: Coxal setal formula 2.2.2.1, all stout basally and tapering; strong process on antero-dorsal margin of coxae II blunt tipped or thumb-like; tarsi II-IV each with 2 clawlike spurs ventro-distally (as those of $P$. madagascariensis Gretillat, Capron and Brygoo, 1959 or $P$. nadchatrami Fain, 1964); ambulacrum well developed.

Gnathosoma: $265 \mu \mathrm{m}$ long (palps included) by $120 \mu \mathrm{m}$ wide; total length of chelicera $220 \mu \mathrm{m}$; digits $10 \mu \mathrm{m}$ long distally and $80 \mu \mathrm{m}$ long by $30 \mu \mathrm{m}$ wide at expanded base; 3 pairs of hypostomal setae and a pair of gnathosomal setae present ventrally.

Type material: Holotype female and a paratype female from Hypsipetes amaurotis amaurotis, Brown-eared Bulbul (Pycnonotidae), Shizuoka Pref., Japan, 25 Nov., 1957. Four paratype females from Hypsipetes amaurotis amaurotis, Kyoto Pref., Japan, 14 Apr., 1977 and 6 Jan., 1981. The holotype and 3 paratypes are deposited in the collection of the National Science Museum, Tokyo, and the rest in the Department of Parasitology, Aichi Medical University, Aichi, Japan.

This new species is related to Ptilonyssus pycnonoti Fain, 1956, (=P. pycnonoti malayi Fain, 1963) reported from Pycnonotus barbatus tricolor in Ruanda-Urundi, Belgian Congo.

The new species differs from $P$. pycnonoti in having many long satae ventrally on the opisthosoma, and in having paired and truncated setae on tarsi II-IV. Further, the new species bears basally thickened and tapering setae on coxae instead of simple setae of $P$. pycnonoti.

\section{Rhinonyssus himantopus Strandtmann, 1951}

(Fig. 5)

Rhinonyssus himantopus Strandtmann, 1951, J. Parasitol., 37: 136.

Rhinonyssus strandtmanni Fain and Johnston, 1966, Bull. Soc. R. Zool. Anvers, 38: 25.

Female. Idiosoma $780 \mu \mathrm{m}$ in length and $550 \mu \mathrm{m}$ in maximum width, egg-shaped, broadly rounded posteriorly.

Dorsum: Podosomal plate $430 \mu \mathrm{m}$ long by $335 \mu \mathrm{m}$ wide at level of coxae IV, roughly triangular, with mildly convex posterior margin, covering greater part of podosoma, and lacking seta. Stigma without peritreme at level of coxae IV. Postero-lateral end of body with a pair of simple setae (approximately $40 \mu \mathrm{m}$ in length). Venter: Sternal plate outlined irregularly; 3 pairs of pores on the plate, with 3 rd pores including minute setae; 1st and 2nd pairs of pores probably including minute setae. Opisthosoma with 10 pairs of simple setae (approximately 25 $\mu \mathrm{m}$ in length).

New record in Japan: 19 from Charadrius placidus japonicus, Japanese Long-billed Ringed Plover (Charadriidae), Kanagawa Pref., 15 Apr., 1956.

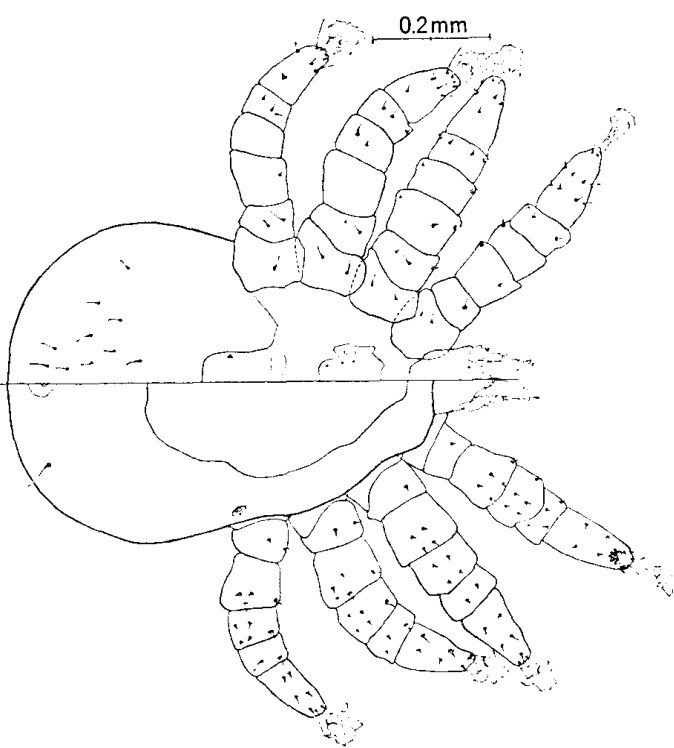

Fig. 5 Rhinonyssus himantopus: dorsal (right) and ventral (left) halves. 
Previous records: This mite was originally described from Himantopus mexicanus (Recurvirotridae) in North America by Strandtmann (1951). Host and localities so far record are as follows: from Himantopus mexicanus, Recurvirostra americana and Charadrius vociferus in North America (Strandtmann, 1956, 1959; Pence, 1972a), Charadrius tricollaris, Hemiparra crassirotris and Himantopus himantopus in Africa (Fain, 1956a, 1957a), Erythrogonys cinctus, Lobibyx novaehollandiae, L. miles, Charadrius melanops (Charadriidae) and Himantopus leucocephalus (Recurvirostridae) in Australia (Domrow, 1966, 1969, 1979), Himantopus mexicanus in Cuba (Černý and Dusbábek, 1970). Fain and Johnston (1966) described $R$. strandtmanni from Charadrius vociferus in North America and from C. tricollaris in Africa, and Pence (1972a) recorded it from $C$. vociferus in North America. Although $R$. strandtmanni Fain and Johnston, 1966 was once separated from $R$. himantopus, Domrow (1969) synonymized $R$. strandtmanni with $R$. himantopus. The specimen from Charadrius placidus japonica (Charadriidae) in Japan was intermediate form between $R$. himantopus and $R$. strandtmanni of Fain and Johnston (1966). Therefore, the present authors identified that specimen as $R$. himantopus following Domrow (1969).

\section{Sternostoma technaui (Vitzthum, 1935)}

(Fig. 6)

Sternostomum technaui Vitzthum, 1935, J. Orn. Lpz., 83: 569.

Rhinonyssus technaui de Castro, 1948, Arq. Inst. Biol. Sao Paulo, 18: 257.

Sternostoma technaui Strandtmann, 1951, J. Parasitol., 37: 139.

Sternostoma turdi Zumpt and Till, 1955, J. Entomol. Soc. South Afr., 18: 85.

Sternostoma spatulatum Furman, 1957, Hilgardia, 26: 480.

Sternostomoides technaui Bregetova, 1965, Entomol. Obozr., 44: 709.

Sternostoma borceanum Feider and Mironescu, 1968, Ann. Stiint. Univ. Al. I. Cuza, 14: 105. New synonymy.

Sternostomoides orlandoi Dusbábek, 1969, Folia Parasitol. (Prague), 16: 225.

New synonymy.

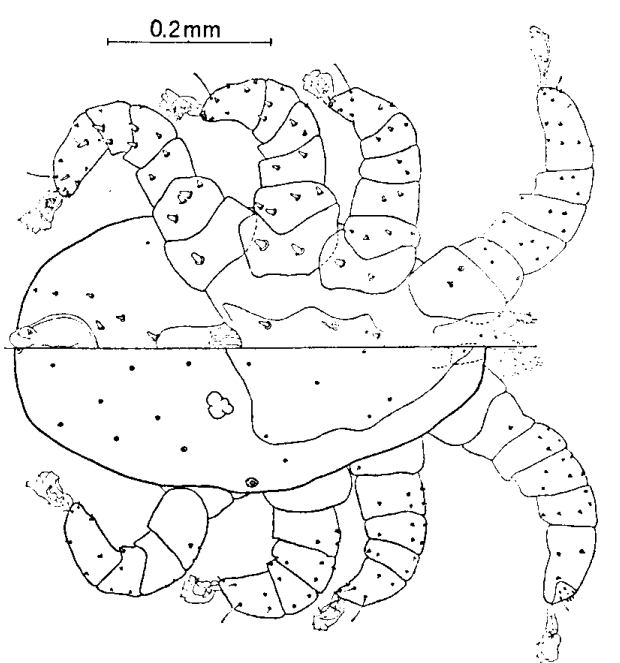

Fig. 6 Sternostoma technaui: dorsal (right) and ventral (left) halves.

Sternostomoides spatulatum Černý and Dusbábek, 1970, Acarologia, 12: 486.

Female. Idiosoma $590 \mu \mathrm{m}$ in length and $370 \mu \mathrm{m}$ in width.

Dorsum: Podosomal plate $320 \mu \mathrm{m}$ long by $270 \mu \mathrm{m}$ wide, strongly sclerotized, roughly triangular, with convex posterior margin. Opisthosoma with 8 pairs of minute setae. Venter: Sternal plate weakly sclerotized; 3 pair of stout setae on the plate (approximately $17 \mu \mathrm{m}$ long). Genital plate $115 \mu \mathrm{m}$ long by $55 \mu \mathrm{m}$ wide; a paired blunt-tipped setae at posterior margin. Opisthosoma with 5 pairs of blunt-tipped setae. Anal plate 100 $\mu \mathrm{m}$ in length and $85 \mu \mathrm{m}$ in width; adanal setae at level of posterior border of anus. Legs: Coxal setal formula 2.2.2.1, all spatulate setae; tarsi II-IV each ventrally with 3 pairs of small, blunt-tipped setae.

New records in Japan: 10 우 and 1o from Turdus naumanni euromus, Dusky Thrush (Turdidae), Gifu Pref., 14 Nov., 1979. 1우 from Turdus dauma toratugumi, Golden Mountain Thrush (Turdidae), Saitama Pref., 29 Jun., 1956.

Previous records: S. technaui was originally described from Cinclus cinclus aquaticus (Cinclidae) in Europe. Additional specimens were taken from $C$. cinclus aquaticus in Belgium (Fain 1963a), from Oreocincla lunulata (Turdidae) in Australia (Domrow, 1969), from Turdus migratorius in North America (Pence, 1972b), from $T$. olivaceus 
in South Africa (Zumpt and Till, 1955), from $T$. olivaceus geraueri and $T$. abyssinicus baraka in Africa (Fain, 1956a, 1957a), from $T$. musicus, $T$. philomelus philomelus, $T$. pilaris and $T$. merula merula in Belgium (Fain, 1962, 1963a), from T. merula and T. philomelus in Austria (Fain et al., 1974), from $T$. fumigatus and $T$. nudigenis in Trinidad (Fain and Aitken, 1967), from Hylocichla ustulata ustulata (Turdidae) and $H$. guttata in North America (Furman, 1957; Pence, 1972b), from Cinclus pallasi, Turdus philomelos, $T$. pilaris, $T$. merula, Oreocincla dauma and Hylocichla minima in USSR (Bregetova, 1965), from Turdus viscivorus, $T$. pilaris, $T$. ericetorum and $T$. torquatus in Rumania (Feider and Mironescu, 1968), and from Catharus fuscescens fuscescens and Mimocichla plumbea rubripes (Turdidae) in Cuba (Dusbábek, 1969; Černý and Dusbábek, 1970). Our present specimen is closely related to $S$. orlan$d o i$ and $S$. borceanum in the $S$. technauigroup, and also is simliar to $S$. technaui that illustrated by Pence (1975). But Domrow (1969) reported that $S$.turdi and $S$. spatulatum were considered as the synonym of $S$. technaui. From these results it seems that $S$. borceanus and $S$. orlandoi are a synonyms of S. technaui.

\section{Rallinyssus caudistigmus Strandtmann, 1948}

(Fig. 7)

Rallinyssus caudistigmus Strandtmann, 1948, J. Parasitol., 34: 512.

Rallinyssus caspicus Butenko, 1976, Parazitologiya (Leningr.), 10: 72.

Female. Large form. Idiosoma 1,000 $\mu \mathrm{m}$ in length and $600 \mu \mathrm{m}$ in width, elongate oval in shape.

Dorsum: Podosomal plate $365 \mu \mathrm{m}$ long by $308 \mu \mathrm{m}$ wide at maximum: posterior and postero-lateral margins convex. Stigma with short peritreme at the posterior end of body. Venter: Sternal plate with strongly irregular outline and bilaterally asymmetric, $95 \mu \mathrm{m}$ long by $140 \mu \mathrm{m}$ wide at maximum, 3 pairs of sternal setae free in cuticle. Genital plate narrow, flanked by 2 genital setae. Anal pore surrounded by a large circular membrane, outer circular line $240 \mu \mathrm{m}$, and inner

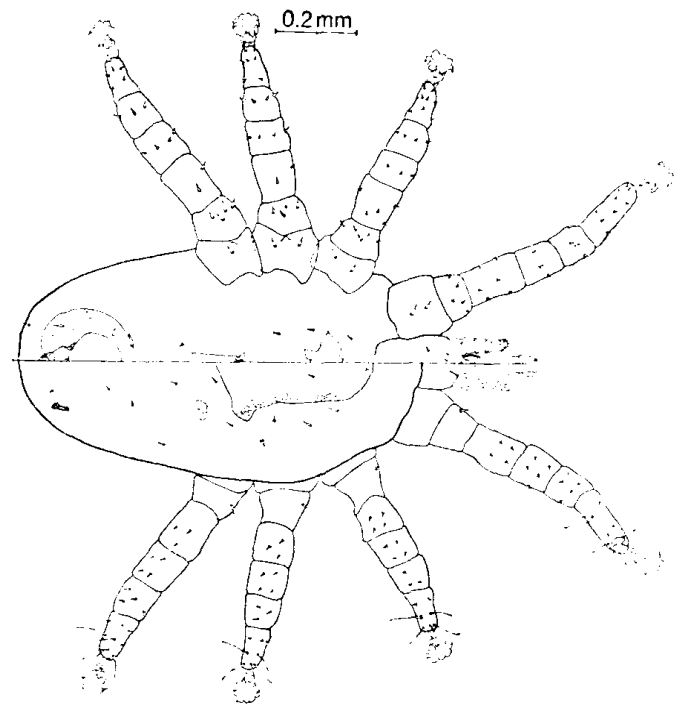

Fig. 7 Rallinyssus caudistigmus: dorsal (right) and ventral (left) halves.

one $130 \mu \mathrm{m}$ in diameter, with 4 pairs of stout based and tapering setae (approximately $30 \mu \mathrm{m}$ long) on the membrane. Anal plate small, and cribrum present, with a pair of stout based and tapering anal setae, and unpaired minute seta on the plate.

New records in Japan: 3qq, from Gallinula chloropus indica, Indian Moorhen (Rallidae), Amani Island, Kagoshima Pref., 26 Dec., 1959.

Previous records: The genus Rallinyssus has been recorded only from the nasal passage of birds of the family Rallidae. This genus is easily distinguished from other genera by its stigma with short peritreme at the posterior end of the body. Rallinyssus caudistigmus was originally described from the Furica americana and Rallus elegans (Rallidae) in Texas, North America (Strandtmann, 1948). Since then, it has been recorded from Fulica cristata in South Africa (Fain, 1959), Gallinula tenebrosa and $F$. atra in Australia (Domrow, 1966, 1969), Gallinula tenebrosa in New Guinea (Wilson, 1968), F. americana in North America (Pence, 1972a), $F$. atra in Rumania (Feider and Mironescu, 1973), and from Gallinula chloropus in Austria (Fain et al., 1974). Rallinyssus caspicus was described from Fulica atra and Gallinula chloropus in the southwestern part of the Caspian Sea by Butenko (1976). 


\section{Ruandanyssus terpsiphonei Fain, 1957} (Fig. 8)

Ruandanyssus terpsiphonei Fain, 1957, Ann. Parasitol. Hum. Comp., 32: 148.

Ruandanyssus terpsiphonei terpsiphonei $\mathrm{Sa}-$ kakibara, 1968, J. Med. Entomol., 5: 17.

Ruandanyssus terpsiphonei echongi Sakakibara, J. Med. Entomol., 5: 15.

Female. Idiosoma $420 \mu \mathrm{m}$ in length and $270 \mu \mathrm{m}$ in width, elongate oval in shape.

Dorsum: Podosomal plate $245 \mu \mathrm{m}$ long by $185 \mu \mathrm{m}$ wide, well developed, anterior and lateral margins rounded, posterior margin straight; anterior margin and central region each with paired relatively short setae (approximately $15 \mu \mathrm{m}$ in maximum length), remaining 7 pairs of setae long (approximately $52 \mu \mathrm{m}$ in maximum length). Opisthosomal plate $195 \mu \mathrm{m}$ long by $140 \mu \mathrm{m}$ wide at maximum, roughly triangular; anterior margin straight and posterior tip truncate or slightly rounded; a pair of simple setae $(23 \mu \mathrm{m}$ in length) anteriorly and a pair of minute setae at posterior end. Venter: Sternal plate $70 \mu \mathrm{m}$ long by $92 \mu \mathrm{m}$ wide at maximum; $1 \mathrm{st}$ and 2nd sternal setae on the plate, 3rd sternal setae off the plate. Metasternal seta present on the soft integument. Opisthosoma ventrally with 6 pairs of setae (approximately

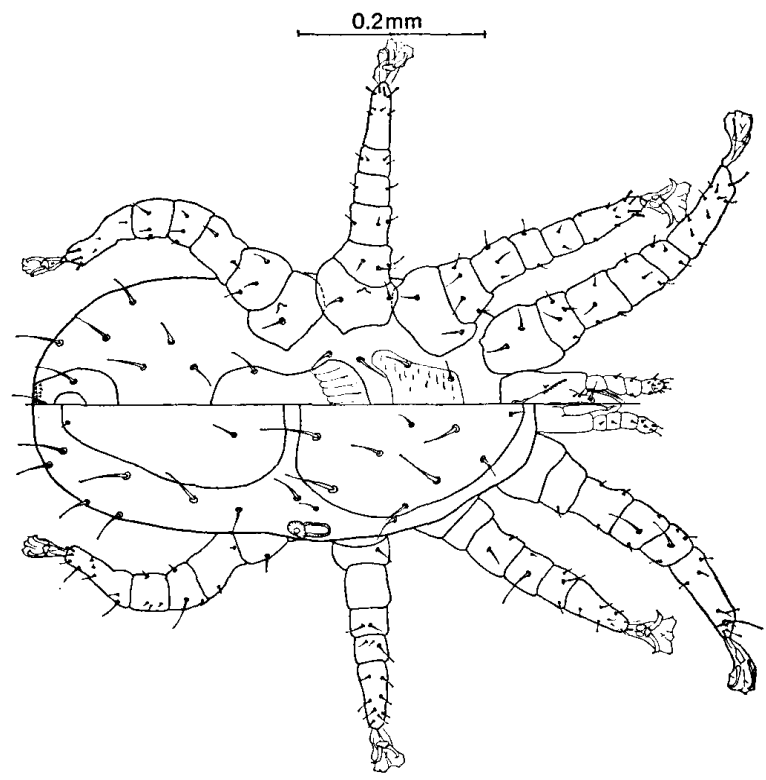

Fig. 8 Ruandanyssus terpsiphonei: dorsal (right) and ventral (left) halves.
$40 \mu \mathrm{m}$ in maximum length). Legs: Coxal setal formula 2.2.2.1, all simple setae; gcnu I and tibia I each with a long seta (approximately $45 \mu \mathrm{m}$ in length) dorsally; tarsi II-IV each with 4 rod-like setae $(10 \mu \mathrm{m}$ in length) distally. Tritosternum bifurcate and pilose laciniae; deutosternum present.

New record in Japan: 19, from Pericrotus roseus divaricatus, Ashy Minivet (Campephagidae), Shizuoka Pref., 29 Apr., 1954.

Previous records: This species was originally recorded from Terpsiphonei viridis kivuensis (Muscicapidae) in Africa by Fain (1957b). Further records are given from Monarcha trivirgata and Myiagra rubecula (Muscicapidae), Struthidea cinerea (Corvidae), Coracina novaehollandiae, C. robsta and Lalage tricolor (Campephagidae), $\mathrm{Pa}$ chycephala rufiventris, $P$. pectoralis and $P$. griseiceps (Pachycephalidae), Sericornis frontalis (Sylvidae) and Artamus personatus (Artamidae) in Australia (Domrow, 1965, 1967, 1969, 1979). Sakakibara (1968) described subspecies $R$. terpsiphonei echongi from Pachycephala sp. in New Guinea. Our present specimen is well in agreement with the subspecies $R$. terpsiphone $i$ echongi in all morphological features. However, the subspecies $R$. terpsiphonei echongi was synonymized with $R$. terpsiphonei by Domrow (1969). Therefore, we identified this specimen as Ruandanyssus terpsiphonei according to Domrow (1969).

\section{AGknowledgements}

We are grateful to Dr. R. Domrow, Queensland Institute for Medical Research, Dr. A. Fain, Institute of Tropical Medicine, Antwerp, Dr. D. B. Pence, Texas Tech University, School of Medicine, and to Prof. Dr. N. Wilson, University of Northern Iowa, for providing us with their valuable papers.

\section{REFERENCES}

Bregetova, N. G. (1965): Generic grouping of the rhinonyssid mites (Mesostigmata, Rhinonyssidae), parasites of birds. I. The new genus Sternostomoides. Entomol. Oborz., 44: 709-713 (in Russian).

Butenko, O. M. (1969): Zoogeographic analysis of mites of the Family Rhinonyssidae (Gamasoidea, Parasiformes) of the USSR fauna. Zool. Zh., 48: 207-211 (in Russian). 
Butenko, O. M. (1976): Rhinonyssid (Gamasoidea: Rhinonyssidae), parasites of the rails from the region of the Lenkoran hibernation site. Parazitologiya, 10: $72-77$ (in Russian).

Castro, M. P. de (1948): Reestruturaçāo genérica da famillia "Rhinonyssidae Vitzthum, 1935" (Acari: Mesostigmata: Gamasides) e descriçāo de algumas espécies novas. Arq. Inst. Biol. Sao Paulo, 18: 253-284.

Černý, V. (1969): Six new nasal mites (Mesostigmata, Ptilonyssidae) from Cuban birds. Folia Parasitol. (Prague), 16: 227-235.

Černý, V. and F. Dusbábek (1970): The nasal mites of Guban birds. II. Ptilonyssidae and Rhinonyssidae (Acarina: Mesostigmata). Acarologia, 12: 479-491.

Cruz, J. de la (1971): Nuevas adiciones a la acarofauna parásite (Acarina: Hypoderidae y ptilonyssidae) de las Aves de Cuba. Poeyana Inst. Biol. Acad. Cienc. Cuba, 90: 1-6.

Domrow, R. (1964): Fourteen species of Ptilonyssus from Australian birds (Acarina, Laelapidae). Acarologia, 6: 595-623.

Domrow, R. (1965): New laelapid nasal mites from Australian birds. Acarologia, 7: 430-460.

Domrow, R. (1966): Some mite parasites of Australian birds. Proc. Linn. Soc. N. S.W., 90: 190-217.

Domrow, R. (1967): Rhinonyssine nasal mite infections in birds at Mitchell River Mission during the wet and dry seasons. Proc. Linn. Soc. N. S. W., 91: 211-219.

Domrow, R. (1969): The nasal mites of Queensland birds (Acari: Dermanyssidae, Ereynetidae and Epidermoptidae). Proc. Linn. Soc. N. S. W., 93: 297-426.

Domrow, R. (1972): Bird nasal mites in New Zealand. Tuatara, 19: 99-100.

Domrow, R. (1979): Three collections of Rhinonyssine nasal mites from Queensland birds. Acarologia, 20: 485-516.

Dusbábek, F. (1969): New species of nasal mites (Acarina: Rhinonyssidae) from Cuban birds. Folia Parasitol. (Prague), 16: 213-226.

Ehara, S. (1980): Illustrations of the Mites and Ticks of Japan, 562 pp., Zenkoku Nosonkyoiku kyokai, Tokyo (in Japanese).

Fain, A. (1956a): Les Acariens de la famille Rhinonyssidae Vitzthum, 1935 parasites des fosses nasales des Oiseaux au Ruanda-Urundi (Note Préliminaire). Rev. Zool. Bot. Afr., 53: 131-157.

Fain, A. (1956b): Note complémentaire sur les Rhinonyssidae au Ruanda-Urundi. Rev. Zool. Bot. Afr., 53: 392-398.

Fain, A. (1957a): Les acariens des familles Epidermoptidae et Rhinonyssidae parasites des fosses nasales d'oiseaux au Ruanda-Urundi et au Congo belge. Ann. Mus. R. Congo Belge (Tervuren), 60: $1-176$.

Fain, A. (1957b): Essai de classification des Rhinonyssidae (Acari: Mesostigmata) avec description de deux genres nouveaux. Ann. Parasitol. Hum. Comp., 32: 145-157.

Fain, A. (1959): Further notes on nasal mites from South Africa, with description of a new genus and five new species. J. Entomol. Soc. South Afr., 22: 18-34.

Fain, A. (1962): Les Acariens parasites nasicoles des oiseaux de Belgique. I. Deux especes novelles de Rhinonyssidae (Mesostigmata) avec une liste des especes connues de Belgique. Bull. Ann. Soc. R. Entomol. Belg., 98: 252-270.

Fain, A. (1963a): Les Acariens nasicoles des oiseaux de Belgique. II. Description de deux especes nouvelles. Bull. Ann. Soc. R. Entomol. Belg., 98: 168-181.

Fain, A. (1963b) : Nouveaux Rhinonyssidae (Acarina: Mesostigmata). Rev. Zool. Bot. Afr., 68: 61-85.

Fain, A. (1964): Acariens nasicoles de Malaisic. III. Description de deux noureaux Rhinonyssidae (Mesostigmata). Bull. Ann. Soc. R. Entomol. Belg., 100: 63-67.

Fain, A. and T. H. G. Aitken (1967): Les Acariens parasites nasicoles des oiseaux de Trinidad (Indes Occidentales). I. Rhinonyssidae: Mesostigmata. Bull. Inist. R. Sci. Nat. Belg., 43: $1-44$.

Fain, A. and T. H. G. Aitken (1968): Acariens nasicoles d'oiseaux et de mammifères du Brésil. I. Rhinonyssidae de la région de Belém (Nord Brésil). Bull. Inst. R. Sci. Nat. Belg., 44: 1-28.

Fain, A. and T. H. G. Aitken (1969): Acariens nasicoles d'oiseaux et de mammifères du Brésil. III. Nouvelles especòs de Rhinonyssidae de la région de Belem (Nord Brésil). Bull. Ann. Soc. R. Entomol. Belg., 105: 342-415.

Fain, A. and K. E. Hyland (1963): Deux nouveaux Rhinonyssides communs aux faunes d'Amerique du Nord et de Belgique. Bull. Ann. Soc. R. Entomol. Belg., 99: 375-386.

Fain, A. and D. E. Johnston (1966): Nouveaux acariens nasicoles d'oiseaux nord-americains (Acari: Rhinonyssidac). Bull. Soc. R. Zool. Anvers, 38: 25-41.

Fain, A. and M. Nadchatram (1962): Acariens nasicoles de Malaisie. II. Rhinonyssidae (Mesostigmata) et Turbinoptidae (Sarcoptiformes). Bull. Ann. Soc. R. Entomol. Belg., 98: 271-282.

Fain, A., W. Sixl and Ch. Moritsch (1974): The nasal mites of the family Rhinonyssidae with description of a new species (Acarina). Mitt. Abt. Zool. Landesmus. Joanneum, 3: 129-137.

Feider, Z. and I. Mironescu (1968): Nouvelles espéces de Rhinonyssidae (Parasitiformes) para- 
sites sur les oiseaux. An. Stiint. Univ. Al. I. Cuza, 4: 105-120.

Feider, Z. and I. Mironescu (1973): Deux rhinonyssidae parasites sur Fulica atra de Roumanie. An. Stiint. Univ. Al. I. Cuza, 19: 159-169.

Ford, H. G. (1961): Ptilonyssus constrictus, a new species of avian nasal mite (Acarina: Rhinonyssidae). Acarologia, 3: 139-146.

Furman, D. P. (1957): Revision of the genus Sternostoma Berlese and Trouessart (Acarina: Rhinonyssidae). Hirgardia, 26: 473-495.

George, J. E. (1961): The nasal mites of the genus Ptilonyssus (Acarina: Rhinonyssidae) occurring in some North American passeriform birds. J. Kans. Entomol. Soc., 34: 105-132.

Gretillat, S., A. Capron and E. R. Brygoo (1959) : Acariens Rhinonyssidae de Madagascar; Parasites des fosses nasales et des poumons d'oiseaux Malgaches. Acarologia, 1: 375-384.

Hachisuka, M., N. Kuroda, N. Kuroda, T. Mishima, H. Morioka, T. Udagawa and Y. Yamashina (1958): A Hand-List of the Japanese Birds (4th ed.), 264 pp., The Ornithology Society of Japan, Tokyo.

Hyland, K. E. and A. Moorhouse (1970): Nasal mites from Mexican birds. I. Rhinonyssidae (Mesostigmata) from the hosi family Tyrannidae. Acarologia, 12: 43-58.

Kadosaka, T., K. Kaneko and K. Asanuma (1983): New records of avian nasal mites (Acari: Rhinonyssidae) from Japan. Jpn. J. Sanit. Zool., 34: 221-227.

Kaneko, K. (1973): Three new records of nasal mites from columbiform birds in Japan. Jpn. J. Sanit. Zool., 23: 308 (in Japanese).

Kaneko, K. (1977): Classification and biology of endoparasitic mites. In: Contribution to Acarology in Japan (eds., Sasa, M. and J. Aoki), pp. 345-370, Hokuryukan, Tokyo (in Japanese).

Kaneko, K., Y. Matsudaira and Prince Masahito (1978): Endoparasitic mites of anatid birds collected in Chiba and Saitama prefectures, Japan (Acarina: Rhinonyssidae and Ereynetidae). Jpn. J. Sanit. Zool., 29: 147-154 (in Japanese).

Pence, D. B. (1972a): The nasal mites of birds from Louisiana. I. Dermanyssids (Rhinonyssidae) from shore and marsh birds. J. Parasitol., 58: 153-168.

Pence, D. B. (1972b): The nasal mites of birds from Louisiana. II. The genus Sternostoma (Dermanyssidae: Rhinonyssinae). J. Parasitol., 58: 781-789.

Pence, D. B. (1972c): The nasal mites of birds from Louisiana. IV. The genus Ptilonyssus (Dermanyssidae: Rhinonyssinae) with a description of two new species. J. Parasitol., 58: 11621169.

Pence, D. B. (1973): The nasal mites of birds from Louisiana. VIII. Additional records and description of a new species (Acarina: Dermanyssidae, Ereynetidae, Epidermoptidae and Cytoditidae). J. Parasitol., 59: 874-880.

Pence, D. B. (1975): Keys, species and host list, and bibliography for nasal mites of North American birds (Acarina: Rhinonyssinae, Turbinoptinae, Speleognathinae and Cytoditidae). Spec. Publs. Mus. Tex. Tech Univ., 8: 1-148.

Pence, D. B. and S. D. Castro (1976): Studies on the variation and morphology of the Ptilonyssus "sairae" comples (Acarina: Rhinonyssidae) from north american passeriform birds. J. Med. Entomol., 13: 71-95.

Ramsay, G. W. (1970): The first records of an avian nasal mite from New Zealand. $N . Z$. Entomol., 4: 93-94.

Sakakibara, I. (1968): New species and records of birds nasal mites from New Guinea (Acari: Mesostigmata, Rhinonyssidae). J. Med. Entomol., 5: 13-20.

Spicer, G. S. (1977): Two new nasal mites of the genus Ptilonyssus (Mesostigmata: Rhinonyssidae) from Texas. Acarologia, 18: 594-601.

Spicer, G. S. (1978): A new species and several new host records of avian nasal mites (Acarina: Rhinonyssinae, Turbinoptinae). J. Parasitol., 64: 891-894.

Spicer, G. S. (1984) : Nasal mites from birds of a Guatemalan cloub forest (Acarina: Rhinonyssidae). J. Parasitol., 70: 794-802.

Strandtmann, R. W. (1948): The mesostigmatic nasal mites of birds. I. Two new genera from shore and marsh birds. J. Parasitol., 34: 505514.

Strandtmann, R. W. (1951): The mesostigmatic nasal mites of birds. II. New and poorly known species of Rhinonyssidae. J. Parasitol., 37: 129-140.

Strandtmann, R. W. (1956): The mesostigmatic nasal mites of birds. IV. The species and hosts of the genus Rhinonyssus (Acarina: Rhinonyssidae). Proc. Entomol. Soc. Wash., 58: 129142.

Strandtmann, R. W. (1959): New records for Rhinonyssus himantopus and notes on other species on the genus. J. Kans. Entomol. Soc., 32: 132-136.

Vitzthum, H. G. (1935): Milben aus der Nasenhöhle von Vogeln. J. Ornithol., 83: 563-587.

Wilson, N. (1968) : Records of nasal mites (Mesostigmata: Rhinonyssidae) from New Guinea, Philippines and United States. J. Med. Entomol., 5: 211-223.

Wilson, N. and G. E. Haas (1980) : Ectoparasites (Mallophaga, Diptera, Acari) from Alaskan birds. Proc. Entomol. Soc. Wash., 82: 541-552. Zumpt, F. and W. M. Till (1955): Nasal mites 
of birds hitherto known from the Ethiopian Region, with keys and description of nine new species (Acarina: Laelaptidae). J. Entomol. Soc. South Afr., 18: 60-92.

\section{摘 要}

日本産鼻腔内寄生ダニの

新種，新記録種

国内で採集された鳥類の鼻腔内寄生ダ二を整理した
ところ，1 新種と7 新記録種が明らかとなった。こ こで，新種を記載し，既知種を図を加えて報告した。 宿主と 8 種のダニの関係は, ヒヨドリ：Ptilonyssus hiyodori n. sp., メジロ : Ptilonyssus ruandae Fain, 1956, , コカワラヒワ:P. sairae Castro, 1948, ツグ $ミ$ : P. euroturdi Fain and Hyland, 1963, イカルチ ドリ: Rhinonyssus himantopus Strandtmann, 1951, トラッグミおよびッグミ: Sternostoma technaui (Vitzthum), 1935, バン: Ralliny'ssus caudistigmus Strandtmann, 1948, サンショウクイ:Ruandany'ssus terpsiphonei Fain, 1957 のとおりであった. 